
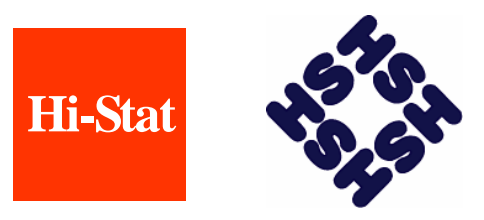

Discussion Paper Series

No.84

\title{
The Extent and History of \\ Foreign Direct Investment in Japan
}

Ralph Paprzycki and Kyoji Fukao

April 2005

Hitotsubashi University Research Unit for Statistical Analysis in Social Sciences A 21st-Century COE Program

Institute of Economic Research Hitotsubashi University Kunitachi, Tokyo, 186-8603 Japan http://hi-stat.ier.hit-u.ac.jp/ 


\title{
The Extent and History of Foreign Direct Investment in Japan
}

\author{
Ralph Paprzycki* \\ and \\ Kyoji Fukao**
}

April 2005

\begin{abstract}
The past few decades have seen a significant rise in foreign direct investment (FDI) worldwide. While Japanese companies have actively contributed to this trend, FDI in Japan continues to be much lower than in other countries. This paper explores the history of both outward and inward FDI in Japan, looking in particular at the reasons for the low levels of inward FDI. New calculations for this paper - based on data from the Establishment and Enterprise Census - show that foreign firms' role in the Japanese economy may be substantially larger than the most frequently cited published statistics suggest. In some industries (motor vehicles and electrical machinery in particular), inward FDI penetration, as measured by the share of employment accounted for by foreign affiliates, in Japan in fact is on par with the United States. However, a large number of "sanctuaries" with almost no foreign involvement remain, so that FDI penetration overall is still very low. While to some extent, this can be explained by Japan's relatively isolated geographic location, historical factors play an important role. Throughout the centuries and until quite recently, Japan's rulers have viewed foreign involvement in the economy as a threat and consequently erected various barriers to FDI, which are discussed in detail.
\end{abstract}

\footnotetext{
Correspondence:

*Ralph Paprzycki, Institute of Economic Research, Hitotsubashi University, Naka 2-1, Kunitachi, Tokyo 186-8603. E-mail: ralphp@ier.hit-u.ac.jp

** Kyoji Fukao, Institute of Economic Research, Hitotsubashi University, Naka 2-1, Kunitachi, Tokyo 186-8603. E-mail: k.fukao@srv.cc.hit-u.ac.jp
} 


\section{Introduction}

The past few decades have seen rapid advances towards a truly global economy, driven, to a large extent, by the growing role of multinational corporations (MNCs) and their activities around the world. Japanese companies have vigorously participated in this trend, both through exports and through foreign direct investment. However, when it comes to Japan as a market place for foreign companies, the country has lagged far behind: generating roughly $12 \%$ of global GDP, Japan accounts for only 5\% of worldwide merchandise imports and, even after the boom in recent years, for just $1 \%$ of global inward FDI. ${ }^{1}$ In most other developed countries, foreign firms have come to play an important part in overall economic activity, making sizeable contributions to capital formation and employment. This is not the case in Japan: as new calculations in this paper show, using employment as an indicator, foreign firms' role in the Japanese economy may be substantially larger than the most frequently cited published statistics suggest. Nevertheless, compared with countries such as the United States, Germany, or the UK, Japan's inward FDI penetration remains conspicuously low.

One important reason, of course, is geography. An island nation situated on the edge of a continent of which it is by far the most economically advanced, Japan has enjoyed none of the natural advantages that have facilitated cross-border trade and investment in other parts of the world such as Europe, where countries share land borders as well as cultural and linguistic roots. But geography provides only part of the answer. Of similar, if not greater importance, is Japan's economic and political history over the past few centuries which has shaped attitudes and policies towards foreign business in the country: with the exception of a few brief interludes, foreign business involvement in the Japanese economy has predominantly been seen as a threat to national aspirations.

The situation of FDI in Japan today can only be understood in a broader, historical context, which the following sections aim to provide. They begin with a brief overview of worldwide trends in FDI and the substantial contribution Japanese firms have made to these trends from a relatively early period onwards; discuss the extent of foreign direct investment in Japan and related problems in obtaining reliable and internationally comparable data; and finally, they look at explanations of the low level of FDI in Japan, focusing in particular on the history of government policies towards inward foreign investment.

\section{Global FDI trends and Japan's outward investment}

While the extent of global economic integration we see today is a new phenomenon, crossborder business activities are not. Trading between different lands can be traced back to the dawn of recorded human history more than 4,000 years ago, and by the first millennium CE, vast networks of commercial exchange spanning Asia, Africa, and Europe had sprung up. International business activities experienced a significant boost when advances in transportation and transborder communications during the sixteenth and seventeenth century ushered in the age of merchant capitalism, giving rise to the establishment of such wellknown trading firms as the British and Dutch East India Companies. But it was only with the advance of industrial capitalism in the nineteenth century that cross-border activities

\footnotetext{
${ }^{1}$ Percentage shares are authors' calculation based on data for 2003 from World Bank, WTO, and UNCTAD websites. Both Japan's share in global FDI inflows and in global inward FDI stock in 2003 were around 1.1\%. For comparison: Japan's share in global merchandise exports was $6.5 \%$, while its share in global outward FDI stock in 2003 was $4.1 \%$.
} 
significantly extended beyond trading and banking to include foreign investments in plantations, mines, factories and distribution facilities. By the onset of the First World War in 1914 , according to one estimate at least US\$14.5 billion had been invested around the world by non-resident individuals or firms and first-generation migrants. ${ }^{2}$ By far the most important home countries of foreign direct investment were Britain, the birthplace of the industrial revolution, and the United States, followed by France and Germany. However, even at this early stage, Japanese firms already were playing a not insignificant role, accounting for about $2 \%$ of global accumulated FDI in $1914 .^{3}$ Japanese firms had come to control much of the coastal industries and trade of Eastern China, and trading houses such as Mitsui had set up branch offices as far afield as Shanghai, Paris, New York and London.

The upheavals following the First World War and the collapse of international capital markets in the late 1920s and early 1930s curtailed cross-border investment activities, especially in Europe. Nevertheless, cumulated foreign direct investment almost doubled during the interwar period to US\$26.4 billion, largely because US firms had escaped relatively unscathed from the war and continued their rapid overseas expansion. Japanese firms more than doubled their overseas investment during this period: cotton spinners and weavers set up production bases in China, so that in Shanghai, for example, they soon surpassed the British in the number of mills erected. ${ }^{4}$

Following the rupture of World War Two, international trade and investment expanded once more. However, as a result of the devastation of the war in Europe and Japan, foreign direct investment during the 1950s and 1960s was heavily dominated by US firms. Only during the 1970s, after successful reconstruction in Europe and Japan, did firms from these countries once again join the fray in earnest. Finally, rapid economic development in South Korea, Taiwan, and Singapore, among others, has led companies from these countries to become increasingly international in their operations over the past decade or two.

The 1990s, moreover, were a period in which a host of national, regional and worldwide initiatives - such as the launch of the Common Market in Europe, the North American Free Trade Agreement (NAFTA), the completion of the GATT Uruguay Round and foundation of the World Trade Organization (WTO), and the gradual opening of the Chinese economy accelerated the trend towards global economic integration. In the wake of these developments, worldwide FDI flows accelerated during the decade and reached a peak of 1.4 trillion US\$ in 2000 .

A few more figures illustrate the important role that firms' international activities have come to play in the world economy: measured in relation to global capital formation, FDI inflows jumped from $2.3 \%$ in 1980 to a peak of $19.8 \%$ in 2000 before dropping to $7.5 \%$ in 2003 . As a result of this increase, the total worldwide inward FDI stock climbed from $6.6 \%$ of GDP in 1980 to $22.9 \%$ in $2003 .{ }^{5}$ At the same time, the sales of MNCs' foreign affiliate in relation to global GDP more than doubled from $23.1 \%$ to $48.6 \% .{ }^{6}$ Moreover, at US\$17.6 trillion in 2003, the sales of foreign affiliates worldwide were roughly twice the amount of global merchandise and service exports. ${ }^{7}$

\footnotetext{
${ }^{2}$ Dunning (1993: 116).

${ }^{3}$ Ibid.: 117.

${ }^{4}$ For details on Japanese investment in China during this period, see, e.g., Howe (1996: 410-25).

${ }^{5}$ Figures from UNCTAD online database.

${ }^{6}$ Based on figures from UNCTAD (2004), Table I.3.

${ }^{7}$ Based on figures from UNCTAD (2004), Table I.3.
} 
It should be noted, however, that to some extent the term "globalization" is a misnomer when it comes to foreign direct investment, because of the extremely uneven distribution of such flows: developed countries accounted for $90 \%$ of investment outflows during the past ten years (1994-2003) and 70\% of inflows, while developing countries received only $27 \%$ (the remaining 3\% are unaccounted for). But even among developing countries, FDI inflows are highly concentrated in a small number of countries, with China (including Hong Kong) receiving the lion's share (9.3\% of global inflows), and a string of other East and Southeast Asian countries together accounting for a further 4.3\%. Outside Asia, the only developing countries that account for sizeable shares of global FDI inflows are Brazil (2.6\%) and Mexico (2.1\%). In contrast, most countries of Sub-Saharan Africa, Central and South America, the Middle East, South Asia, the Pacific and Eastern Europe have received only negligible amounts of foreign direct investment.

Turning to Japan's outward FDI flows, a few figures illustrate that the country's firms have actively participated in and contributed to the substantial increase in cross-border business activities. At the end of 2003, Japan's cumulative FDI stock stood at US\$335.5 billion, which is $4.1 \%$ of the world total. These figures put Japan in sixth place, behind the United States, the United Kingdom, France, Germany, and the Netherlands. Japan's low rank may be surprising considering that it has the second largest economy in the world. However, compared with the nations of the West, Japan is an economic late-comer and the country's firms were still busy catching up during the 1960s and 1970s. They therefore possessed little technological or managerial know-how that they could have profitably employed overseas. What is more, even if they had wanted to invest abroad, they would have found it difficult to do so: reflecting official concern about the country's shortage of foreign exchange, the government restricted outward direct investment until 1968 and liberalization was not complete until 1972.

Even following liberalization, FDI outflows did not amount to much more than a trickle: benefiting from a favorable exchange rate, Japanese companies preferred to serve overseas markets through exports rather than FDI. It was therefore only when growing trade friction with the major trading partners of the West and rapid appreciation of the yen during the second half of the 1980s rendered this strategy increasingly difficult that Japanese firms began to invest abroad in earnest. The "bubble economy" added further fuel, allowing Japanese companies go on a shopping spree overseas and buy up real estate, banks, and other companies, especially in the United States. As a result, annual Japanese FDI outflows soared more than twenty-fold from 2.4 billion US\$ in 1980 to a peak of 50.5 billion US\$ in $1990 .^{8}$

However, reflecting the burst of the "bubble economy" in the early 1990s and the ensuing stagnation of the domestic economy, Japanese FDI outflows have since contracted again. Nevertheless, a considerable number of the largest and best-known MNCs in the world today are Japanese. While the notification data by the Ministry of Finance suggest that the service sector accounts for about two-thirds of all outward FDI, Japan's most conspicuous multinationals in fact hail from the manufacturing sector, ${ }^{9}$ and it is Japan's most successful

\footnotetext{
8 On a balance of payments basis. Source: UNCTAD, Country Profile: Japan, Table 3c; online: $<$ http://www.unctad.org/sections/dite_fdistat/docs/wid_cp_jp_en.pdf $>$ (accessed 6 Jan. 2005).

${ }^{9}$ This is in fact less contradictory than it might at first seem. Approximately one-fifth of Japan's cumulative outward FDI for the period 1989-2003 is accounted for by the financial sector alone. However, while the financial assets and hence the recorded FDI flows involved in this sector tend to be large, its economic weight in terms of employment or value-added is considerably smaller. What is more, the industry breakdown of FDI flows provided by the Ministry of Finance is on a gross basis, i.e. disinvestments - potentially of a similar size are not taken into account. Most analysts therefore believe that net outflows in the service industry in fact are smaller than those in the manufacturing sector. Finally, it should be noted that much Japanese outward FDI in the service sector during the "bubble period" was real estate related and subsequently encountered huge capital
} 
industries - especially the automobile and electronics industries - that have been most aggressive in investing abroad. As a result, these industries are rapidly becoming as internationally oriented as their counterparts in Europe or the United States. Though the overseas production ratio of the Japanese manufacturing sector as a whole still lags considerably behind that of United States or Germany, the ratios for the electrical machinery and automobile industries at $26.5 \%$ and $47.6 \%$ are rapidly catching up. ${ }^{10}$

Much of the outward FDI in the auto and electronics industry consists of the relocation of production to low-cost countries in the rest of Asia. In Japan, this transfer of production, coupled with hardly any growth of the domestic economy, has led to concerns about the "hollowing-out" of the country's industrial base. Such concerns, voiced not only in the press, but also by some officials and academics, however, often fail to appreciate the important role that outward FDI plays in the restructuring of the economy. ${ }^{11}$ The relocation of activities, especially of low-value-added assembly processes, not only frees domestic resources to be employed in higher value-added activities. It also helps to support those stages of the value chain that do remain at home, for example by strengthening the competitiveness of domestic companies overall or providing cheaper parts and components for those products that continue to be made in Japan.

Foreign direct investment - by Japanese firms and companies worldwide - plays an important part in the deepening of the international division of labor. However, not all countries have participated in this trend to the same extent or in the same way: for example, less than a dozen countries account for most outward and inward FDI originating from and going to developing economies. Even among the developed countries, considerable differences persist, largely as a result of their (economic) history as well as their geographic location. Thus, we find that countries like the UK and the Netherlands occupy shares in global outward and inward FDI stocks that far outweigh the size of their economies: both countries were among the earliest nations to industrialize, have been international in their outlook due to their history as colonial powers, and are at the heart of an increasingly integrated Europe. In contrast, Japan is not only a latecomer to industrialization, but also has been inward-looking for much of its history and finds itself at the periphery of a continent that to this day is ruled by political and economic regimes of all imaginable shades. Nevertheless, the level of Japan's outward FDI has been rapidly catching up with that of other industrialized nations. Inward FDI, however, continues to lag considerably behind.

\section{The extent and nature of FDI in Japan}

Assertions that inward FDI in Japan is extremely low have become almost axiomatic. No matter which measure of international comparison is chosen, the limited extent of inward

\footnotetext{
losses, providing another reason why the economic weight of Japanese service-sector FDI is much smaller than manufacturing-sector FDI even though MOF figures suggest otherwise.

${ }^{10}$ In 1997, the last year for which METI provides an international comparison, the overseas production ratio in the Japanese manufacturing sector overall stood at only $12.4 \%$, compared with $27.7 \%$ for the U.S. and $32.1 \%$ for Germany. The figures for the electrical machinery industry were: Japan 20.8\%, U.S. 25.7\%, Germany 32.6\%, while in the transportation machinery industry they were: Japan 30.8\%, U.S. 47.3\%, Germany 53.9\%. The figures in the text, which are for 2002, mean that in these two sectors, Japan has more or less reached the same levels as the other two countries four years earlier. In contrast, the overseas production ratio for the Japanese manufacture as a whole, at $17.1 \%$ in 2002 , still remained far below that of the U.S. and Germany.

${ }^{11}$ For a brief discussion of the role of outward direct investment in the restructuring of the Japanese economy, see Blomström, Gangnes, and La Croix (2001).
} 
foreign direct investment, and hence foreign companies' role, in the Japanese economy stand out. A figure often cited in the late 1980s and early 1990s was that foreign direct investment accounted for less than 1 percent of the value of assets or of the share of sales or employment in Japan. ${ }^{12}$ However, though based on data published by Japan's Ministry of International Trade and Industry (MITI; now Ministry of Economy, Trade and Industry, METI), this figure has been shown to substantially understate the actual level of inward FDI. ${ }^{13}$ The conflicting evidence highlights the difficulties in obtaining reliable data on the extent of foreign direct investment in Japan, itself an indication of the low importance Japan's authorities have attached to inward FDI in the past. What indicators are available show that the situation is no longer as black-and-white as it used to be: a number of statistics certainly do show that foreign investment in Japan is much smaller than in other comparable countries, but other figures suggest that the gap has substantially narrowed.

There is no shortage of statistics showing that inward FDI in Japan remains conspicuously low. For example, most advanced countries are both major foreign investors and major recipients of foreign investment; their ratios of outward to inward FDI stocks consequently lie somewhere between one and two. In Japan's case, however, there is a large imbalance and the outward FDI stock outstrips the inward FDI stock by a factor of 4 . What is more, measured in relation to GDP, Japan's inward FDI stock in 2003 stood at only 2.1\%, compared with around $20-40 \%$ for the three largest European economies - Germany, France and the United Kingdom - and $14.1 \%$ for the United States. In fact, even in South Korea, which has not been particularly welcoming to foreign direct investment until quite recently, the inward FDI stock now exceeds 7\% of GDP. In most other advanced countries, FDI inflows, moreover, make a sizeable contribution to gross fixed capital formation: for the period 1998-2003, the average annual share in the US and the three largest European economies was 9-25\%; in Japan, it did not even reach $1 \% .^{14}$

One important reason for the low level of FDI in Japan has been the almost complete absence of cross-border mergers and acquisitions (M\&A), at least until the late 1990s. Such crossborder M\&As have been the main mode of FDI entry in recent years, especially in developed countries. ${ }^{15}$ Yet, even tiny Switzerland, with only one-eighteenth of Japan's population, attracted more M\&A capital inflows in every single year from 1990-98 than the world's second-largest economy. What is more, even when Japan experienced its recent FDI boom, all the other major economies - the US, the UK, Germany, France - as well as Canada, the Netherlands and Australia received more M\&A investment than Japan.

The logical consequence of low levels of inward FDI is that the role of foreign companies in the Japanese economy remains limited. The OECD, for example, suggests that, in 1998, the share of industrial production generated by majority-owned foreign affiliates in Japan was less than $2 \%$, while in the other OECD countries, it ranged from $10 \%$ (Germany) to more than $70 \%$ (Ireland). Similarly, while in the UK and France, such affiliates accounted for more than $17 \%$ and $27 \%$ of domestic employment, respectively, the comparable figure for Japan came to only $0.8 \% .{ }^{16}$ However, the data for Japan in these comparisons is based on METI's annual survey on Trends in Business Activities of Foreign Affiliates in Japan, the reliability of which is questionable because, among other things, it suffers from a low response ratio and does not include affiliates of foreign firms in the real estate and financial sectors. Another set of figures

\footnotetext{
${ }^{12}$ See Feenstra (1998).

${ }^{13}$ See, e.g., Weinstein (1997).

${ }^{14}$ All figures from or based on data provided in UNCTAD (2004).

${ }^{15}$ UNCTAD (2003: 15).

${ }^{16}$ Source: OECD (2001). The UK figure is for 1997.
} 
on the employment by foreign affiliates in the manufacturing sector in host economies is provided by UNCTAD. This set of figures, also for 1998, confirms that the relevant share for Japan was much smaller than for other countries, but at 1.8\% - compared with around 15 to $22 \%$ in the US, Germany, the UK, and France (see Figure 1) - it was more than twice as high as in the OECD study. ${ }^{17}$

\section{Insert Figure 1}

The different figures suggest that measurements of the extent of FDI penetration crucially depend on what data and definition are used. Given the low response rate of METI's Trends in Business Activities of Foreign Affiliates in Japan, a more reliable dataset is provided by the Establishment and Enterprise Census (published by the Statistics Bureau, Ministry of Internal Affairs and Communications), which is compulsory, covers all firms in Japan, and includes information on foreign ownership. This dataset also has the advantage that it allows the calculation of employment shares using different definitions of foreign ownership. Doing so yields results suggesting that FDI penetration in Japan may not be quite as low as the above comparisons suggest (see Table 1). Using the $33.4 \%$ foreign ownership ratio (which corresponds to the definition of Trends in Business Activities of Foreign Affiliates in Japan and allows for multiple foreign owners, so that this definition may include cases of portfolio investment), the employment share by foreign affiliates certainly is very low: despite the increase in recent years, it remains below $2 \%$ for the manufacturing sector and is barely above $1 \%$ for the economy as a whole. However, the results change quite dramatically when we change the definition somewhat and concentrate on those firms with only one foreign owner holding a stake of $20 \%$ or more. This is the definition allowed by the data that comes closest to the one used by the United States, ${ }^{18}$ though it should be noted that it is in fact somewhat stricter than the US definition, which uses only a $10 \%$ foreign-ownership ratio (one single owner). Based on this definition, the employment share by foreign affiliates in Japan overall is still quite low at $2.75 \%$ (2001), but this now is almost half the level found in the United States in 1997. What is more, the value for the manufacturing sector now reaches $5.91 \%$, considerably higher than in the estimates provided by METI, the OECD and UNCTAD, and more than half the level found in the United States (1997). In contrast, the share in the service sector remains quite low at $2.04 \%$, though this, too, is almost half the level registered in the US (see Table 1).

Data that allow a similar definition for the 1996 survey in order to compare the trend in these shares unfortunately are unavailable. Using, however, the definition employed by METI (33.4\% ownership or more by one or more foreign firms), shows that foreign companies have made significant inroads in the intervening five-year period: Both in the manufacturing and in the service sector, the employment share of foreign affiliates increased by more than $40 \%$.

\section{Insert Table 1}

\footnotetext{
${ }^{17}$ UNCTAD (2002), Table I.6. The divergence between the OECD and the UNCTAD figures is probably largely due to differing definitions. While the OECD study only includes firms that are majority foreign-owned, UNCTAD uses a much lower cut-off ratio (generally $10 \%$ ).

${ }^{18}$ Bureau of Economic Affairs, Foreign Direct Investment in the United States: Establishment Data for 1997, online: <http://www.bea.gov/bea/ai/iidguide.htm\#FDIUS> (accessed 18 Feb. 2005).
} 
Japan is less unusual when it comes to the composition of inward FDI. In line with patterns in other developed countries, the majority of cumulative FDI flows into Japan over the past decade-and-a-half has gone into the service sector. Moreover, and again in line with trends elsewhere, there has been a further shift in FDI away from manufacturing and towards services in recent years: while the former accounted for $43 \%$ of cumulative FDI inflows during 1989-97, this share dropped to only 28\% during 1998-2003. Conversely, the share of non-manufacturing sectors (i.e. services, given the lack of any significant investment in the primary sector) in total FDI inflows increased from $57 \%$ to $72 \%$ (see Table 2 ).

Insert Table 2

However, an analysis of the composition of FDI inflows also reveals that these are heavily concentrated in a small number of industries: only two - the chemical and the machinery industry - account by far for the largest share of all foreign investment in the manufacturing sector. The same goes for the service sector, where finance \& insurance, trading, telecommunications and other business services make up the lion's share. Most other sectors have attracted hardly any foreign direct investment at all.

For a more detailed picture of the sectoral pattern of foreign companies' presence in Japan, it is useful to return to Table 1. This confirms that the employment accounted for by foreign affiliates is heavily concentrated in the chemical industry (chemical products, drugs \& medicine) and the machinery industries (general machinery, electrical machinery, motor vehicles \& parts, miscellaneous transport equipment, and precision instruments). However, rather than indicating that the other manufacturing sectors are closed to foreign direct investment, this pattern suggests that foreign companies invest in those industries in which Japan possesses a comparative advantage, the knowledge-intensive industries. Nevertheless, compared with the United States, where the share of employment accounted for by foreign affiliates is at least $4 \%$ in every single industry, and well in excess of $10 \%$ in many, the concentration in Japan is conspicuous. At the same time, though, this heavy concentration also means that, following the recent wave of foreign investment in the car industry, foreign affiliates' employment share in the motor vehicles \& parts industry as well as the miscellaneous transport equipment industry may now be higher than in the US.

Government regulations - of FDI and of market entry more generally - play a larger role in explaining patterns in the service sector. Much of the recent increase in service sector FDI has been concentrated in four industries: telecommunications, insurance, banking, and business services. These are the industries at the center of recent liberalization measures, and along with the jump in FDI in these industries, employment by foreign affiliates has increased rapidly. In fact, the employment shares by foreign affiliates in the finance and insurance industries and in computer programming and information services in Japan (using the single owner definition) in 2001 exceeded the level observed in the United States in 1997.

Yet, there are also a number of industries that have remained "sanctuaries", where foreign companies are virtually absent. If we define as "sanctuaries" industries in which foreign affiliates account for less than $0.5 \%$ of employment, no matter which foreign-ownership definition is chosen, these include construction \& civil engineering, utilities (electricity, gas, water, etc.), real estate, medical services, health $\&$ hygiene, and other personal services. These are industries which do not always readily lend themselves to foreign direct investment; yet, the equivalent share in the US in each of these sectors nevertheless ranges between 1 and $2 \%$. 
The reason for the absence of FDI in these industries in Japan in most cases is not the existence of outright bans or restrictions on foreign companies - though some do remain - but rather the presence of regulations that restrict market access more generally.

Overall, foreign direct investment and the role foreign companies play in the economy remain much smaller in Japan than in other industrialized countries. The gap may not be quite as large as the most frequently cited measures, many of which are based on highly unsatisfactory data, suggest. And at least in some sectors - the car industry, finance and insurance being prime examples - FDI penetration these days in fact seems to be on par with that in the United States. Nevertheless, and despite recent increases, FDI in Japan remains limited both in its overall economic weight and in its breadth in terms of the number of industries it has reached.

\section{Why is foreign direct investment in Japan so low?}

The low level of foreign direct investment in Japan has been the subject of intense debate among businessmen, policy makers, and academics. Western observers have frequently claimed that, along with its "unfair" trade practices, Japan has failed to create a "level playing field" by allowing foreign companies to invest in the country. Even when most formal trade and investment barriers were removed in the 1970s and 1980s, other structural impediments remained. ${ }^{19}$ The official Japanese reply to such allegations during that period often was that rather than any barriers to trade and investment, the true reason for low investment and import levels was the lack of sufficient effort and commitment by foreign companies in a demanding and out-of-the-way market. ${ }^{20}$

Because Japan's low FDI penetration is often seen as the result of a more general "closedness" of the economy, it is useful to digress for a moment and consider Japan's international trade. This is relevant to FDI because companies that enter a foreign market often do so by first exporting to that country; only when they have established a foothold allowing them to gain experience in the local market do they typically consider setting up local operations in order to better meet local customers' needs. ${ }^{21}$ The lack of such a foothold providing market recognition, an established customer base, access to the distribution system, etc. - significantly increases the risk and initial costs that any direct investment would involve. It therefore matters that Japan's purchases of goods and services from abroad in relation to GDP, at $10.2 \%$, are the lowest among the 30 OECD countries. In fact, Japan's import ratio has actually fallen since the 1970s and 1980s, while it has risen for most other OECD countries. $^{22}$ Considering, moreover, that approximately one-fifth of Japanese merchandise imports consist of mineral fuels and that the country imports most of its other raw materials, a more relevant indicator may be the ratio of manufactured imports to GDP. But again, no clear trend towards more international integration is visible: hovering between 4.5 and $5.3 \%$ during the period $1980-95$, the ratio rose only slightly to $6.3 \%$ in 2000 , and it seems likely that much of this increase was the result of re-imports of Japanese firms engaged in production abroad. ${ }^{23}$ On the other hand, what is easily overlooked is that Japan's export ratio also is the smallest among the 30 OECD economies. And again, at 11.2\% they were lower in 2003 than in the

\footnotetext{
${ }^{19}$ For a survey of the literature on Japan's trade barriers during this period, see, e.g. Lawrence (1993).

${ }^{20}$ For a popular account of such mutual allegations, see, e.g., Wilkinson (1990: 200-222).

${ }^{21}$ This argument obviously only applies to firms selling tradable goods and above manufactured products.

${ }^{22}$ Authors' calculations based on OECD Online Database.

${ }^{23}$ Figures from Ito and Fukao (2004).
} 
1980s. ${ }^{24}$ Yet, nobody would argue that the country has pursued policies that explicitly discriminate against its own exports.

Japan's low export and import ratios suggest that there may be factors other than explicit barriers to trade and investment that account for the country's limited "openness". Comparing Japan with, for example, the countries of the European Union, the latter clearly enjoy various trade- and investment-promoting advantages: geographical proximity, shared cultural roots, and, of course, policies aimed at economic integration such as the creation of the Common Market and a common currency, the Euro. In addition, the populations and economies of European countries are smaller, many of them in fact much smaller, than Japan's - another factor accounting for the greater reliance on international trade and investment.

One way to take these differences into account is to estimate a "gravity model" which seeks to analyze trade and investment flows adjusted for aspects such as economic size, geographic distance, and factor endowments. The evidence of studies in this vein suggests that these aspects do indeed explain a large part of Japan's low level of manufactured imports, and once these factors are controlled for, Japan's trade is no longer so different after all. ${ }^{25}$ Thus, what mainly seems to determine the country's low import ratio is its geographic isolation and economic structure, i.e. its poor endowment of natural resources and the large manufacturing sector relative to the economy overall, rather than any discriminatory policies or implicit barriers to trade. ${ }^{26}$

In contrast with the findings on trade, gravity models do produce some evidence suggesting that foreign direct investment is unusually low. One such study for the period 1985-90, for example, comes to the conclusion that Japan is more closed to American FDI than Western European countries. ${ }^{27} \mathrm{~A}$ more detailed gravity model estimate of the regional distribution of overseas sales of US firms' foreign affiliates for the more recent years of 1994, 1999, and 2000, finds that such sales are indeed significantly lower for affiliates in Japan in the manufacturing sector. Yet, no significant difference is found in the case of the service sector, suggesting that in this sector Japan is not more closed than other countries. ${ }^{28}$

On balance, the evidence suggests that the low degree of Japan's international trade integration is not unusual, once the various factors that determine a country's trade patterns are taken into account. In other words, at least in the last two decades, on which the evidence presented here concentrates, Japanese imports have not appear to have been hampered by any obstacles that would set the country apart from other nations - despite the repeated friction Japanese trade has caused. On the other hand, when it comes to foreign direct investment, gravity models do lend support to the conclusion that - at least in the case of the

\footnotetext{
${ }^{24}$ Authors' calculations based on OECD Online Database.

${ }^{25}$ See, e.g., Eaton and Tamura (1994) and Harrigan and Vanjani (2003). In fact, the latter suggest that, once country size, industry output, bilateral distance, and industry fixed effects are controlled for, Japan is actually more open to manufactured imports from the US than vice-versa.

${ }^{26}$ Harrigan and Vanjani (2003). Also see Saxonhouse (1993), who provides a broader overview of the evidence on Japan's trade, including intra-industry trade, international price differentials, and the keiretsu.

${ }^{27}$ Eaton and Tamura (1994).

${ }^{28}$ Fukao, Ito, and Kwon (2004). As an aside, it is interesting to note that the language dummy (for countries in which English is not the dominant language) is statistically significant in most specifications, meaning that American firms tend to prefer investing in countries in which English is spoken, giving some justification to the claim that American firms have been failing to make the effort to overcome language (and, by extension, cultural) differences. On the other hand, geographic distance is found to be statistically insignificant in most specifications, implying that for firms from the US, being located more or less half-way between the major markets of Europe and Asia, Japan is not more "out of the way" than other countries. In other words, the low level of FDI in Japan cannot be explained by the country's distance from the world's leading investor, the United States.
} 
manufacturing sector - Japan is an outlier. One possible explanation is that, at least until recently, FDI in Japan has faced explicit as well as implicit barriers. Another is that the lingering perception that Japan is a difficult market to enter - as evidenced by the large body of literature on the topic - has itself acted as a "mental" barrier. Both explanations are not mutually exclusive, and point to the importance of understanding the history of foreign direct investment in Japan.

\section{From the origins to the end of the Tokugawa shogunate $\left(12^{\text {th }}\right.$ century-1867)}

The dearth of foreign direct investment in Japan is not due to a lack of trying: Throughout the centuries, foreign merchants have attempted to gain access to the Japanese market, but have often met with little success. Among the earliest foreign businessmen in Japan were Chinese traders living in the port town of Hakata (Fukuoka) on Kyushu Island in the $12^{\text {th }}$ century. Commercial exchange between Japan and China during this period, the Kamakura era (11831333) flourished and formal trade relationships were established in 1325 . However, during the $14^{\text {th }}$ and $15^{\text {th }}$ centuries, official trade became more sporadic, though unofficial trade continued to thrive.

The first attempt by Westerners to establish commercial outposts in the archipelago followed soon after Portuguese seafarers first reached Japanese shores around 1543. These early endeavors, in fact, were not without success: visiting the ports of western Japan on a regular basis, Portuguese merchants and their exotic goods - especially their superior weapons technology - were initially well received, and some of the Kyushu daimyo were keen to attract trade with the "Southern Barbarians." The Tokugawa rulers that unified the country and, in 1603, founded the shogunate that was to last until 1868, were also eager for commerce with the outside world. The shogunate thus permitted the Dutch in 1609 and the English four years later to establish trading posts on the island of Hirado, marking the first recorded foreign investments by Westerners in Japan. ${ }^{29}$

Along with trade, however, the Portuguese also brought missionaries to Japan. Having converted several hundred thousand Japanese, including several Kyushu daimyo, to Christianity, the missionaries soon alienated Tokugawa leaders through their aggressiveness and intolerance. Following failed earlier attempts to curtail missionary activity, the country's leaders imposed increasingly stringent controls that also regulated foreign trade and by 1616 left only the two ports of Nagasaki and Hirado open to European ships. In 1635, all Japanese were prohibited, on pain of death, from going abroad.

Failure to engage in profitable trade had led the British East India Company to close its office in Japan as early as 1623. When the Portuguese were expelled in 1639, the only remaining European trading mission was that of the Dutch, and this was moved to the tiny island of Deshima in Nagasaki harbor. With the exception of this isolated outpost, where traders were kept as virtual prisoners, as well as sporadic trade with Korea and China from outlying islands in the south and with Russia and China from Hokkaido in the north, Japan had cut off all contact with the outside world, ushering in the period of sakoku or national isolation.

This isolation lasted more or less undisturbed until the arrival of Commodore Matthew C. Perry and his "Black Ships", ushering in the forced opening of Japan in the 1850s which

\footnotetext{
${ }^{29}$ See Fairbank, Reischauer, and Craig (1973).
} 
resulted in the "unequal treaty" negotiated by U.S. envoy Townsend Harris in 1858. This treaty and similar ones subsequently agreed with Britain, France, and other Western powers deprived Japan of autonomy over its tariffs, granted foreigners extraterritoriality rights, and provided for the opening of a limited number of Treaty ports for foreign business.

Foreign traders subsequently began to settle in the designated port areas and a group of American entrepreneurs established the first US direct investment in the country. Yet, outside the so-called Treaty Settlements, foreign investments continued to be effectively banned. ${ }^{30}$ Nevertheless, most Japanese regarded the growing number of Westerners with suspicion and hostility, and the indecisiveness of the Tokugawa rulers in its dealings with the foreign powers led a group of young samurai leaders to overthrow the shogunate and "restore" imperial rule.

\section{The Meiji era to the end of World War II (1868-1945)}

A central motive of the Meiji restoration had been to maintain Japan's economic and political independence in the face of the threat posed by Western powers. The early Meiji rulers therefore soon moved to restrict the entry of foreign capital and transferred existing foreign interests into Japanese hands. Areas where foreigners continued to be allowed to do business - trade and finance - were rarely worth the trouble: one contemporary described Japan as "the graveyard of the merchant's hopes." ${ }^{11}$ At the same time, the knowledge and technology necessary to meet the central aims of the new government - "enriching the country, strengthening the military" through industrialization - were to be acquired by sending study missions overseas, bringing foreign scholars and experts to Japan, importing capital equipment, and copying foreign products.

The attitude to foreign investment changed with the revision of the commercial law in 1899 . Motivated by difficulties to fund the growing demand for foreign capital equipment and technology after the Sino-Japanese War of 1884-95, this first great capital liberalization granted firms from the United States and numerous European countries the right to invest directly inside the Japanese market. Incentives for foreign firms to invest in the country were strengthened when Japan regained tariff autonomy in 1911 and significantly increased import levies on industrial and other goods. Following the complete freeze of imports of manufactured goods during World War I, tariffs were further increased after the war and again after the 1923 Great Kanto Earthquake, providing ample inducement for "barrier hopping" FDI. ${ }^{32}$

The large majority of foreign investments during this period took the form of joint-ventures, and a number of prominent companies today were born in this way. The pioneer was Nihon Denki - today's NEC - which entered a joint-venture with America's Western Electric (now Lucent Technologies) and through the technology thus obtained became the country's most important producer of vacuum tubes, telephone sets and switching equipment. Further early examples are International Oil (with a 100\% foreign-ownership rate, established in 1900), and Osaka Gas $(54 \%, 1902)$. But the two industries where foreign companies were particularly active and had the largest impact on industrial development in Japan were electrical machinery and automobiles. In addition to Nihon Denki, important foreign investments in the

\footnotetext{
${ }^{30}$ See Mason (1992).

${ }^{31}$ Quoted in Weinstein (1996: 138).

${ }^{32}$ Mason (1992: 20-23).
} 
electrical machinery sector were General Electric's joint-venture with Tokyo Shibaura (now Toshiba) in 1905, the establishment of Fuji Electric as a joint venture between Germany's Siemens and the Furukawa group in 1935, and the founding IBM's subsidiary in Japan in 1937. Meanwhile, in the car industry, both Ford (in 1925) and General Motors (in 1927) established 100\%-owned subsidiaries in Japan for the assembly of imported "knocked down" parts. Though investments in these two industries clearly dominated, the activities of enterprises from the United States and Europe during this period of relative openness spanned a considerable range of sectors, including tires and window glass as well as trading, banking, and shipping. ${ }^{33}$

Yet, despite the relative openness of the Japanese economy during this period, the number of foreign companies operating in the country remained rather limited. According to a survey by the Ministry of Commerce and Industry in 1931, there were only 23 firms that were financed and managed exclusively or mainly by foreigners. Another 36 were owned by both foreigners and Japanese, but management was in the hand of the latter. In addition, there were 29 sales offices of foreign companies in Japan. ${ }^{34}$

This period of relative openness was brought to an end during the 1930s by rising nationalism and militarism in Japan and the international tension this created. The government gradually tightened controls over foreign investment until most companies - including Ford and General Motors - decided to withdraw. With the outbreak of war, U.S. assets in Japan were frozen in 1941, and American and other Allied investments were expropriated to be utilized in the war effort.

\section{The high-speed growth era (1945-1970)}

Following the defeat of Japan, the American Occupation authorities that governed Japan until the country regained full and formal independence in 1952, continued to impose major restrictions based on the fear that FDI would introduce unneeded complications in the postwar reconstruction process and allow foreign companies an unfair advantage to take over weakened and vulnerable Japanese companies. ${ }^{35}$ Foreign firms that had operated in Japan before the war were allowed limited investments, and expropriated capital was returned, but because of the state of the war-devastated economy, many companies - including Ford and General Motors - decided not to seek re-entry. ${ }^{36}$ Measures introduced by the Occupation authorities were the 1949 Foreign Exchange Control Law (FECL) and the 1950 Foreign Investment Law (FIL). While intended to be only temporary, these two laws in fact served as the major instruments by which the Japanese government subsequently screened investment proposals and, more often than not, effectively shut them out for the following two decades.

Japan certainly soon offered a highly attractive market in which to invest. Following the devastation of the war, the economy recovered rapidly and entered a period of sustained highspeed growth: between 1956 and 1970, real GDP expanded at an average annual rate of close to $10 \%$. Moreover, given the government's policy of import-substitution, which relied on substantial tariff and non-tariff barriers, foreign companies that wanted to participate in this rapidly growing market faced considerable incentives to invest in the country. However,

\footnotetext{
${ }^{33}$ See, e.g., Mason $(1987,1992)$, Yuzawa and Udagawa (1990).

${ }^{34}$ Udagawa (1990:3)

35 Mason (1992).

${ }^{36}$ Mason (1992: 146-7).
} 
Article 1 of the FIL stated that foreign investment was permitted only if it "contributed (1) to the attainment of self-sufficiency and the sound development of the Japanese economy and (2) to the improvement of Japan's balance of payments." ${ }^{37}$ In practice, the government applied these provisions in a highly restrictive, case-by-case manner that aimed to discourage most of FDI but to encourage the inflow of foreign technology. Foreign companies that applied to invest in Japan therefore were typically urged to license their technologies to Japanese firms instead. ${ }^{38}$

From the 1960s onwards, though, pressures mounted to liberalize FDI. The government therefore relaxed the screening criteria from admitting only those investments that positively contributed to the Japanese economy to prohibiting those deemed "harmful." That this was hardly an improvement is revealed by the criteria on which proposals were judged, providing officials with ample leeway for interpretation: foreign investment was admitted "as long as it did not (1) unduly oppress small-size enterprises, (2) seriously disturb industrial order, and (3) seriously impede the domestic development of industrial techniques." ${ }^{\text {, } 39}$

Pressure continued to build as Japan joined the OECD and accepted Article 8 of the IMF in 1964, respectively obliging the country to deregulate foreign capital and foreign exchange controls. Liberalization proceeded, but with important exceptions. For example, extensive restrictions remained in those sectors where Japanese firms were deemed to still lack international competitiveness - primarily in the high-tech industries. ${ }^{40}$ These sectors, in fact, were not fully liberalized until the mid-1970s, by which time strong domestic competitors and high labor costs had significantly reduced the attractiveness of investing in these industries. Various barriers to imports also remained in place, preventing foreign companies from pursuing a forward strategy for investment to follow exports. Finally, a limit was set on the ratio of shares a foreign company could acquire in a Japanese firm, making hostile takeovers all but impossible. Given the severe restrictions on FDI during this period, direct investment in manufacturing sector by U.S. firms between 1951 and 1970 never exceeded 67 million US\$ in any single year and the total value for the period amounted to less than 320 million US\$. ${ }^{41}$

\section{The 1970 to the mid-1990s}

The gradualist approach adopted by the Japanese government towards FDI deregulation continued throughout the 1970s, reflecting officials' grudging acknowledgment that the country could no longer ignore the international clamor. Thus, foreign investment in the automobile industry was deregulated in 1971. Further measures in 1973 in principle completely liberalized foreign investment in all areas, with the exception of 22 designated industries. Restrictions on FDI in 17 of these industries were gradually lifted between 1974 and 1976. Investments in retail trade were liberalized in 1975, and in 1980, the Foreign Investment Law was finally abolished altogether: foreigners now only had to notify the authorities rather than to seek their approval prior to a specific investment. Procedures were further simplified in 1992 with the change from prior notification to ex post facto reporting. (See Table 3 for an overview of the process of FDI liberalization in Japan.)

\footnotetext{
${ }^{37}$ Yoshino (1970:349).

38 Mason (1992).

${ }^{39}$ Yoshino (1970:349).

${ }^{40}$ Examples are the manufacture of computers, integrated circuits, pharmaceutics and precision electronic machines (Mason 1992: 204).

${ }^{41}$ Figures from Mason (1992:197).
} 


\section{Insert Table 3}

From a historical perspective, FDI deregulation in the 1970s meant that official policy towards foreign direct became the most liberal it has been since first three decades of the twentieth century. Yet, by the time direct controls were removed, other, indirect barriers had been put in place. To limit the actual effect of capital liberalization, the government took "countermeasures" that included a stricter application of the Anti-Monopoly Law to curb the transfer from foreign companies to their local subsidiaries of technologies not available to Japanese competitors. ${ }^{42}$ More importantly, the private sector erected barriers of its own. Anticipating the inevitable advance of capital liberalization, Japan's firms increased their cross-shareholdings and their business partners from unwanted foreign takeovers (Table 2). ${ }^{43}$ The strategy was not only condoned but in fact supported by the government through the revision of the Commercial Code in 1966, which made it easier for Japanese corporations to issue new shares to third parties of their choice. ${ }^{44}$

It remains a matter of debate whether this increase was a response by Japanese companies to protect themselves and their business partners from unwanted foreign takeover or an unrelated reaction to changes in the tax code in 1966 favoring shareholdings by insurance companies. What is clear, however, is that the change in the tax code as well as a revision of the Commercial Code in the same year, making it easier for Japanese companies to issue new shares to third parties of their choice, were followed by a rapid increase in intra-keiretsu shareholdings.

\section{Insert Figure 2}

In the manufacturing sector, companies in the automobile and electrical machinery industries, for example, strengthened their relationships with suppliers and associated firms by swapping shares, giving rise to the so-called vertical production keiretsu. The mutual shareholdings not only meant that it became virtually impossible for foreigners to acquire companies in these production keiretsu but, by cementing existing business relationship on a long-term basis, also precluded foreign companies from acting as suppliers to the likes of Toyota, Mitsubishi or Hitachi. Similar strategies were pursued by the bank-centered horizontal keiretsu. Crossshareholdings among the members of the six leading keiretsu increased significantly following the liberalization of foreign exchange and capital controls that began in 1964 and 1967, respectively. How pervasive the role of such bank-centered keiretsu came to be is shown by the fact that, in 1988, 89\% of all firms listed on the Tokyo Stock Exchange were member of bank groups. ${ }^{45}$

As a result, by the time that foreigners were allowed to acquire Japanese companies - albeit only with the consent of the target company - following the "complete" liberalization of 1973, cross-shareholdings effectively prevented them from doing so. The abolition of the Foreign

\footnotetext{
${ }^{42}$ Mason (1992:205).

${ }^{43}$ The link between the fear of foreign takeovers and the rise in cross-shareholdings has been questioned by Weinstein (1997). However, most analysts, both foreign and Japanese clearly see these two as closely connected (Mason 1992: 205-207; Miyajima, Haramura, and Enami 2003; Tachibanaki and Nagakubo 1997).

${ }^{44}$ See Mason (1992: 205-207).

${ }^{45}$ Weinstein (1996:151).
} 
Investment Law in 1980, which removed the need for consent of the target company, had little meaning in practice as cross-shareholding ratios remained high throughout the following decade. Foreign companies' preferred mode of entry into developed economies the world over - mergers and acquisitions - thus remained practically unavailable in Japan even following the dismantling of most official barriers to FDI.

This, however, was not the only obstacle. The removal of government regulations exposed a number of other, structural characteristics that served to discourage potential foreign investors. The extent to which these structural features - individually and collectively - represent actual barriers, is a matter of debate. What is clear, however, is that they kept alive the perception, shaped by decades of official obstructions to FDI, that Japan is a very difficult market for foreign companies to enter. Features of the Japanese economy that have frequently been cited as structural impediments are the presence of keiretsu ties, the distribution system, and labor issues. ${ }^{46}$ The keiretsu, in addition to preventing takeovers, have often been seen as making it difficult to break into the Japanese market because members prefer to deal with firms belonging to the same group rather than with outsiders. ${ }^{47}$ The distribution system is relevant because of its multi-tiered structure, consisting of a large number of very small wholesalers and retailers, many of which are organized into distributional groups that pass goods down from manufacturers through various layers of wholesalers and finally to retailers. The scarcity of large, independent distributors which are more likely to stock imported goods and goods manufactured by foreign entrants has meant that foreign firms either had to invest substantial sums in setting up their own distribution network, or they had to negotiate access to distribution channels of established manufacturers. ${ }^{48}$ The specific features of the Japanese labor market have presented a further hurdle to foreign entrants. Much of the job training that in other countries would occur in colleges and universities takes place in the company; job training is often highly company-specific and wages are low initially but rise above a worker's marginal productivity when he (it is rarely a she) approaches retirement, thus rewarding employees that stay with one company throughout their career. This "life-time employment system" has not only discouraged job-hopping but also favored firms with a well-established market position and a reputation for not firing workers, making it difficult for new entrants to hire competent mid-career employees and to attract promising graduates. Japan's unions, which are company-based rather than industry-wide as in the West, and their strong opposition to layoffs have further contributed to the absence of a mid-career labor market. Foreign entrants have therefore not only found it difficult to locate and hire qualified personnel, but have also had to pay substantially higher wages to do so. ${ }^{49}$ Whether these obstacles can be termed "barriers" depends on how one chooses to define these, since many of the structural features do not actively discriminate against foreign companies per se but new market entrants more generally. But if the term "barrier" is defined as any feature of the

\footnotetext{
${ }^{46}$ For a more detailed discussion of these issue, see, for example, Weinstein (1996).

${ }^{47}$ Encarnation (1992:7), for example, suggests that "Japanese oligopolists have moved to replace government regulations with private restrictions on business relationships [....which] deny foreigners access to the Japanese market long after all formal government controls are abolished." Weinstein (1996), in contrast argues, that there is no conclusive evidence to support such assertions. However, in the same volume, Jordan (1996), the president of the American Chamber of Commerce in Japan (ACCJ) at the time, complains that while "[...] companies within a keiretsu grouping cooperate well with each other [...] they will not allow a new company to join them, especially a newly arrived American company."

${ }^{48}$ Belderbos (1998). Again, Weinstein (1996) believes that the distribution system has had little impact on FDI in Japan, while Jordan (1996) in the same volume cites difficulties in penetrating the controlled distribution systems as one important area that adds to the cost of doing business in Japan. The distribution system also featured prominently as an impediment to investment in survey after survey carried out by the ACCJ among its members (Bergsten, Ito, and Noland. 2001).

${ }^{49}$ See Weinstein (1996), Jordan (1996) and Bergsten, Ito, and Noland (2001).
} 
Japanese economy that has impeded market access and therefore lowered FDI, then these characteristics may be considered as barriers.

A range of other factors has often been cited, especially by foreign executives, to explain why FDI in Japan is so low. Top of the list typically is the high cost of doing business in Japan, which is partly the result of the country's economic success. Especially during and after the bubble period, high costs - including land prices, office rents, wages and social costs featured prominently. Other aspects include very progressive individual taxes which make it expensive for foreign companies to dispatch personnel to Japan; the general complexity of doing business in the presence of myriads of regulations; and a lack of transparency when dealing with the government. ${ }^{50}$ Even if domestic companies face the same problems and many foreign firms have managed to penetrate the Japanese market nevertheless, the continuing perception alone that Japan is a difficult or even closed market acts as a barrier in itself.

Actual FDI into Japan during the period from 1970 to 1995 reflects the gradual liberalization process. Annual inflows did increase from less than 200 million US\$ during the first half of the 1970 s to 500 million US\$ at the end of the decade. ${ }^{51}$ They jumped further during the bubble period, reaching a peak of 4.3 billion US\$ in 1991. However, to put these figures into perspective: Japanese FDI outflows during this period were more than ten times as large as inflows. ${ }^{52}$ The growth in FDI inflows during this period therefore seems substantial only because it started from such a low base.

\section{The mid-1990s to the present}

Following the collapse of the stock market and real estate of the 1980s, Japan's economy entered a phase of stagnation from which it has yet to (fully) recover. The prolonged malaise exposed deep-rooted structural problems which provided the impetus for further deregulation of both foreign direct investment and domestic business more generally. Attitudes towards inward FDI changed quite dramatically, to the extent that MITI/METI - which during the 1960s and 1970s played the role of gatekeeper tightly controlling foreign firms' entry into Japan - has transformed itself into one of the most ardent proponents of foreign investment in Japan. Thus, beginning in the early 1990s, not only were FDI procedures simplified; the government also started introducing measures aimed at actively seeking FDI, such as the provision of some tax incentives and support services for foreign companies wishing to invest in Japan. The weight attached to attracting FDI received a further boost with the establishment, in 1995, of the Japan Investment Council, chaired by the prime minister. Finally, in 1998, the government liberalized foreign investment in two important service sectors: telecommunications and broadcasting. Though limits on foreign ownership in these and a range of other sectors - agriculture, mining, air and maritime transportation - remain (see Table 4), these restrictions are, by an large, no longer qualitatively different from similar

\footnotetext{
50 Jordan (1996:197), for example, asserts that “Japanese companies can post up to four or five Japanese executives in the United States for the same amount that it costs an American company to transfer only one American executive to Japan." The general complexity of doing business in Japan ranks prominently in the surveys cited by Bergsten, Ito, and Noland (2001), while Jordan (1996) claims that Japan has the most highly regulated economy among the $\mathrm{G} 7$ nations with more than 11,000 regulations.

${ }^{51}$ Based on MOF data on a notification basis.

${ }^{52}$ These figures Ministry of Finance data and on a notification basis. UNCTAC figures, which are on a balanceof-payments basis, show that there were actually significant negative FDI inflows, i.e. withdrawals, in 1988 and 1989. If the UNCAD figures are used to calculate the ratio between outflows and inflows during the 1987-1992 period, then the former outstripped the latter by a factor of 35 even during this period of "booming" FDI inflows.
} 
barriers to FDI, often for national security reasons, in other advanced economies. In fact, according to one study, by the year 2000, restrictions such as limits on foreign ownership and screening requirements in Japan were no more severe than in most other OECD countries. ${ }^{53}$

\section{Insert Table 4}

More significant than the removal of remaining barriers to FDI, however, were measures to deregulate the economy more generally. As the recession dragged on, it became increasingly clear that overregulation and the presence of public corporations served as a drag on the economy by restricting market access, not only to foreign, but to domestic companies as well. In order to make the economy more flexible and enhance competition, measures were taken to make it easier for companies to spin off subsidiaries and to facilitate mergers and acquisitions (M\&A), and a range of service sectors were deregulated, including such important areas as retail, finance and insurance, and telecommunications.

Details of these measures, as well as their effect on foreign direct investment, are discussed in a separate paper. ${ }^{54}$ Suffice it here to say that, coupled with falling land and share prices, a weak yen, declining cross-shareholdings, a looming crisis in the financial sector, and a growing number of financially distressed companies, these measures set the stage for a surge in inward foreign direct investment, most of which took the form of mergers and acquisitions. Following initial concerns among politicians and in the media about the "fire sale" of Japanese companies as well as fears that foreign managers would initiate mass lay-offs and fail to respect Japanese business practices, public and official attitudes today seem more favorably disposed towards FDI than at any time in the past. To no small extent, it appears, this change in perception owes to the spectacular success of Carlos Ghosn, who has become something of a hero in Japan after turning around ailing automaker Nissan following the takeover by French rival Renault.

The change in attitude is also reflected in the government's aim, announced by Prime Minister Koizumi in January 2003, to double FDI in five years and increase efforts to meet this goal. However, whether this goal can be achieved is questionable. While Japan has made considerable progress in opening its economy to foreign companies, a range of sectors in the non-manufacturing sector continue to be "sanctuaries." In these sectors, which include health care, professional services, energy, and transportation, FDI is hampered not so much by regulations discriminating against foreigners but by entry barriers more generally. Unless deregulation also reaches these sectors, foreign direct investment in Japan is likely to remain below levels seen in other countries.

\footnotetext{
${ }^{53}$ See OECD (2003: 170), where Figure VII.2 shows that Japan scores rather well in terms of these two indicators. The country's poor result overall - it is singled out as one of the countries with the highest levels of overall restrictions (ibid.: 169) - is due to "restrictions on foreign personnel and operational freedom". However, in this area, too, Japan is moving ahead. Working visas are now typically granted for three years rather than just one year as before, and in its "Follow-Up Program for the Promotion of Foreign Direct Investment in Japan" (Cabinet Office; online: <http://www.investment-japan.net/statements/files/20040519.pdf>; accessed 3 Jan. 2005), the government is outlining measures to further ease entry and residence requirements for foreigners working in Japan.

${ }^{54}$ Paprzycki (2004).
} 


\section{Conclusion}

The past few decades have seen an unprecedented rise in worldwide foreign direct investment activity. Japanese companies have actively participated in this trend and count among them some of most recognized names in the world. Yet, the presence of foreign companies is much smaller than in other advanced countries around the world. While the gap may not be quite as large as some of the most frequently cited statistics suggest, Japan nevertheless appears to be an outlier.

Part of the reason is that the country is also an "outlier" in geographical and cultural terms. More important, however, were government policies actively restricting foreign direct investment for much of the past four centuries. And when official barriers began to be gradually replaced from the 1960s onward, structural features of the Japanese economy continued to impede foreign direct investment. Only during the last decade and a half or so have many of these structural impediments also begun to disappear - a consequence of both the government's reform program and changes in business practices resulting from the prolonged recession. Today, Japan is as open to FDI as other advanced economies around the world. Whether this greater openness is sufficient to bring foreign direct investment in Japan in line with levels seen elsewhere, however, is another question. 
References:

APEC (1999), Committee on Trade and Investment, Guide to the Investment Regimes of the APEC Member Economies, Singapore: APEC.

Belderbos, R.E. (1998) 'FDI and Licensing Strategies by Dutch Multinationals in Japan', Research Memoranda NIBOR/RM/98/02, Netherlands Institute of Business Organization and Strategy Research, Maastricht University.

Bergsten, C.F., T. Ito and M. Noland (2001) No More Bashing: Building a New Japan-United States Economic Relationship, Washington, D.C.: Institute for International Economics.

Blomström, M., B. Gangnes, and S. La Croix (2001) Japan's New Economy: Continuity and Change in the Twenty-First Century, Oxford and New York: Oxford University Press.

Dunning, J.H. (1993) Multinational Enterprises and the Global Economy, Wokingham: Addison-Wesley.

Eaton, J. and A. Tamura (1994) 'Bilateralism and Regionalism in Japanese and U.S. Trade and Direct Foreign Investment Patterns', Journal of the Japanese and International Economies 8, 478-510.

Encarnation, D. (1992) Rivals Beyond Trade: America versus Japan in Global Competition, Ithaca: Cornell University Press.

Fairbank, J.K, E.O. Reischauer, and A.M. Craig (1973) East Asia: Tradition and Transformation, Boston: Houghton Mifflin Company.

Feenstra, R. C. (1998) 'Facts and Fallacies about Foreign Direct Investment', University of California, Davis, Department of Economics, Working Paper 98-04; online: $<$ http://www.econ.ucdavis.edu/faculty/fzfeens/pdf/fdi2.pdf $>$ (accessed 18 Feb. 2005).

Fukao, K., K. Ito, and H.U. Kwon (2004) 'Characteristics and Effects of Japan's Inward FDI', An Outline Prepared for the Pre-Conference Meeting of Authors, Conference on International Economic Relations and Structural Change: Issues and Policy Options for Japan and the United States, online: <http://www.fordschool.umich.edu/rsie/ Conferences/CGP/ Mar2004Papers/FukaoItoKwon.pdf> (accessed 18 Feb. 2005).

Harrigan, J. and R. Vanjani (2003) 'Is Japan's Trade (Still) Different?' Journal of the Japanese and International Economies 17, 507-519.

Howe, C. (1996) The Origins of Japanese Trade Supremacy: Development and Technology in Asia from 1540 to the Pacific War, Chicago: The University of Chicago Press.

Ito, K. and K. Fukao (2004) 'Physical and Human Capital Deepening and New Trade Patterns in Japan', NBER Working Paper, No. 10209.

Jordan, T.F. (1996) 'The Future of Foreign Direct Investment in Japan', in M. Yoshitomi and E.M. Graham (eds), Foreign Direct Investment in Japan, Edward Elgar, Cheltenham, UK. 
Lawrence, R.Z. (1993) 'Japan's Different Trade Regime: An Analysis with Particular Reference to Keiretsu', Journal of Economic Perspectives, Vol.7, No.3, 3-19.

Mason, M. (1987) 'Foreign Direct Investment and Japanese Economic Development, 18991931', Business and Economic History 16:93-107.

--- (1992) American Multinationals and Japan: the political economy of Japanese capital controls, 1899-1980, Cambridge, Mass.: Council on East Asian Studies, Harvard University.

MITI, Tsusho Sangyo Seisakushi Hensan Iinkai Hen [MITI and Editing Committee of the History of Trade and Industrial Policy (eds)] (1991) 'Tsusho Sangyou Seisakushi' [The History of Trade and Industrial Policy], vol.8, MITI.

Miyajima, H., K. Haramura, and Y. Enami (2003) 'Sengo Nihon no Kabushiki Shoyu Kozo: Antei Kabunushi no Keisei to Kaitai" [Ownership Structure of Postwar Japanese: The Emergence and Dissolution of Stabilized Shareholdings], Financial Review, No.68, Policy Research Institute, Ministry of Finance; online: <http://www.mof.go.jp/freview/r68/r_68_203_236.pdf $>$ (accessed 27 Jan. 2005).

Nakamura, Y., K. Fukao, and M. Shibuya (1997) 'Tainichi chokusetsu toshi wa naze sukunai ka? Keiretsu, kisei ga mondai ka?' [Why is FDI into Japan so small? Is it because of the keiretsu or because of regulations?], Tsusho Sangyo Kenkyusho Kenkyu Series [MITI Research InstituteStudy Series], No.31, Ministry of International Trade and Industry, Tokyo; online: <http://sv021.rieti.go.jp/mitiri/downloadfiles/m4331-1.pdf> (accessed 22 February 2005).

OECD (2001) Measuring Globalization: The Role of Multinationals in OECD Economies, Paris: OECD.

OECD (2003) OECD Economic Outlook, No. 73, June, Paris: OECD.

Paprzycki, R. (2004) 'What Caused the Recent Surge of FDI into Japan?', Hi-Stat Discussion Paper Series, No. 31, Hitotsubashi University; online: < http://hi-stat.ier.hit-u.ac.jp/ research/discussion/2004/pdf/D04-31.pdf $>$ (accessed 18 Feb. 2005).

Sangyo Kenkyusho [Industry Research Institute] (1983) 'Gaishikei seizogyou no ritchi no jittai ni kan suru chosa hokokusho' [Report on the Actual Situation of the Location of Foreign-owned Manufacturing Firms], Sangyo Kenkyusho.

Saxonhouse, G. (1993) 'What Does Japanese Trade Structure Tell Us About Japanese Trade Policy?' Journal of Economic Perspectives, Vol.7, No.3 (Summer), 21-43.

Tachibanaki, T. and R. Nagakubo (1997) 'Kabushiki Mochiai to Kigyo Kodo' [Shareholdings and Enterprise Behavior], Financial Review, No.43, Policy Research Institute, Ministry of Finance; online: <http://www.mof.go.jp/f-review/r43/r_43_158_173.pdf $>$ (accessed 27 Jan. 2005).

Udagawa, M. (1990) 'Business Management and Foreign-Affiliated Companies in Japan 
before World War II', in T. Yuzawa and M. Udagawa (eds), Foreign Business in Japan before World War II: proceedings of the Fuji Conference, University of Tokyo Press, Tokyo: Japan.

UNCTAD (various years) World Investment Report, New York: United Nations.

Weinstein, D. (1996) 'Structural impediments to investment in Japan: what have we learned over the last 450 years?', in M. Yoshitomi and E.M. Graham (eds), Foreign Direct Investment in Japan, Edward Elgar, Cheltenham, UK.

--- (1997) 'Foreign Direct Investment and Keiretsu: Rethinking U.S. and Japanese Policy", in Robert C. Feenstra, ed. The Effects of U.S. Trade Protection and Promotion Policies, Chicago: Univ. of Chicago Press, 81-116.

Wilkinson, E. (1990) Japan versus the West: Image and Reality, Harmondsworth: Penguin.

Yoshino, M.Y. (1970) 'Japan as host to the international corporation', in C.P. Kindleberger (ed.), The International Corporation: a symposium, Cambridge, Mass.: MIT Press.

Yuzawa, T. and M. Udagawa (eds), Foreign Business in Japan before World War II: proceedings of the Fuji Conference, University of Tokyo Press, Tokyo: Japan. 
$\underline{\text { Tables and Figures }}$

Figure 1: Japan's inward and outward FDI position in international comparison

(a) Inward FDI stock/GDP (2003; \%)

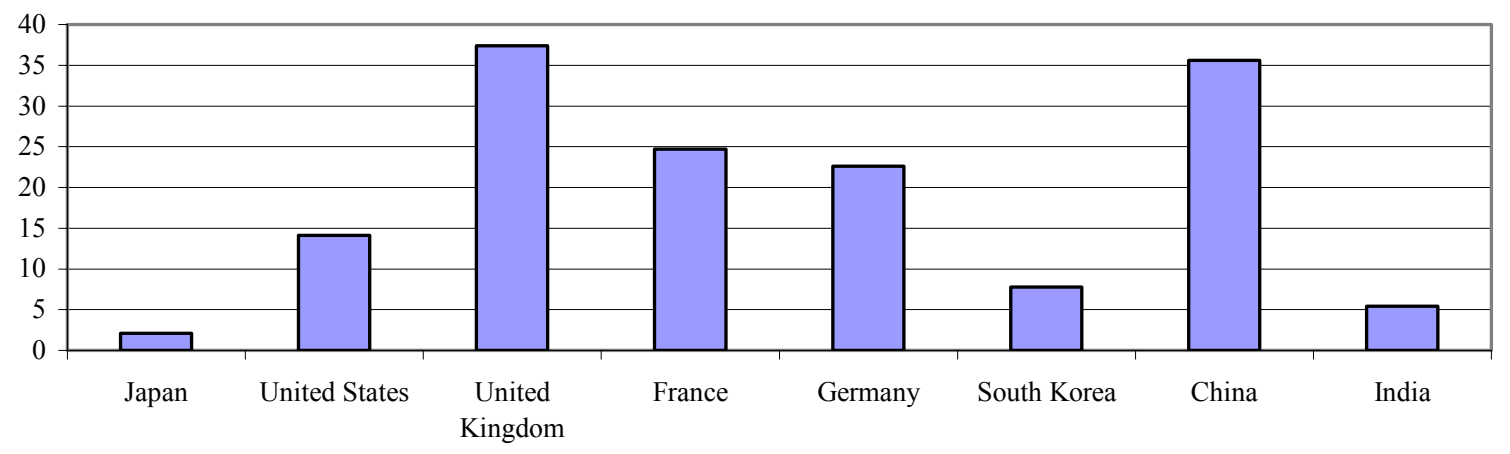

Source: UNCTAD (2004).

(b) Outward FDI stock/GDP (2003; \%)

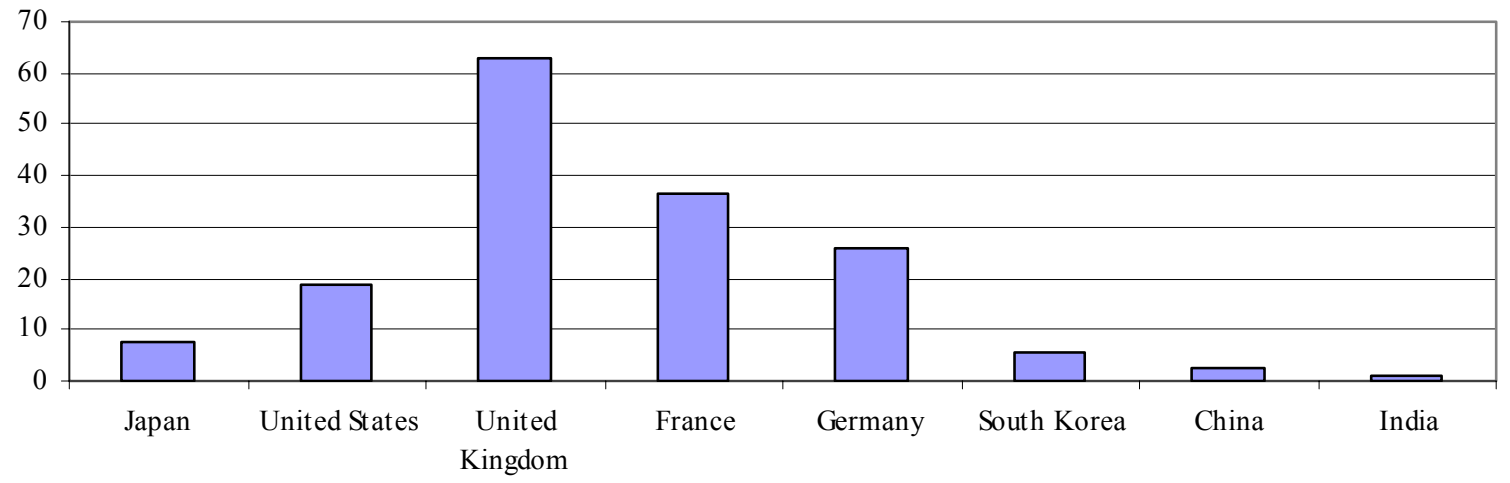

Source: UNCTAD (2004).

(c) Inward FDI flows/gross fixed capital formation (Average 2000-2003, \%)

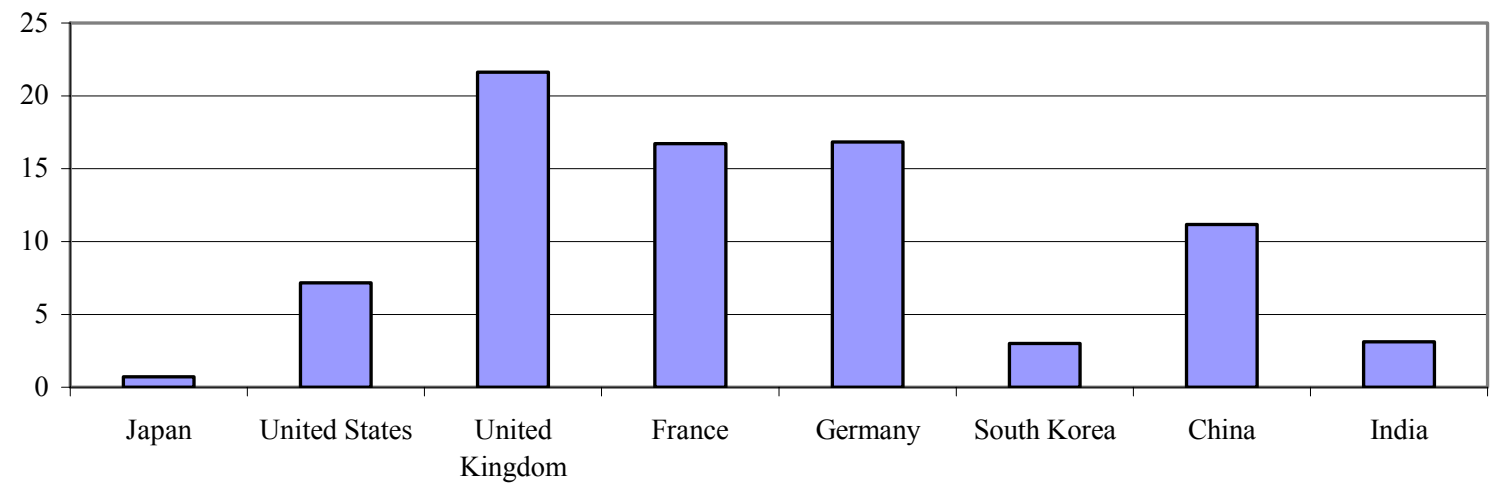

Source: Authors' calculations based on UNCTAD (2004). 
(d) Share of no. of employees of foreign-owned affiliates in total manufacturing sector employment (1998; \%)

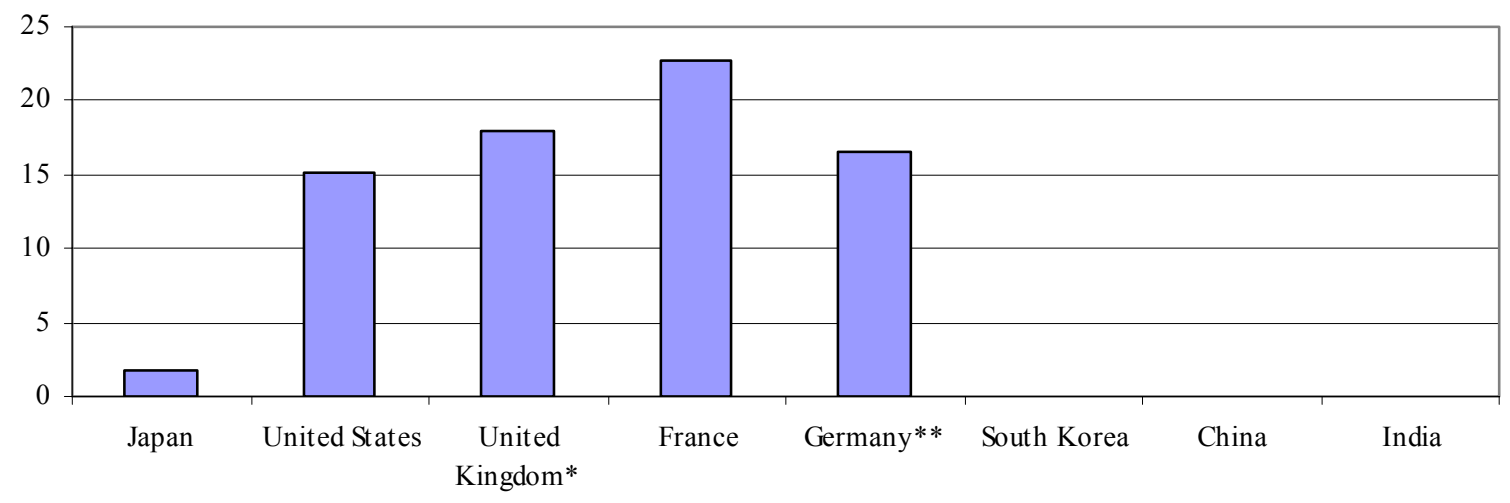

Source: UNCTAD (2002), Table I.6.

Notes: * 1997, ** 1994.

Figure 2: Intra-keiretsu shareholding ratio ( percent)

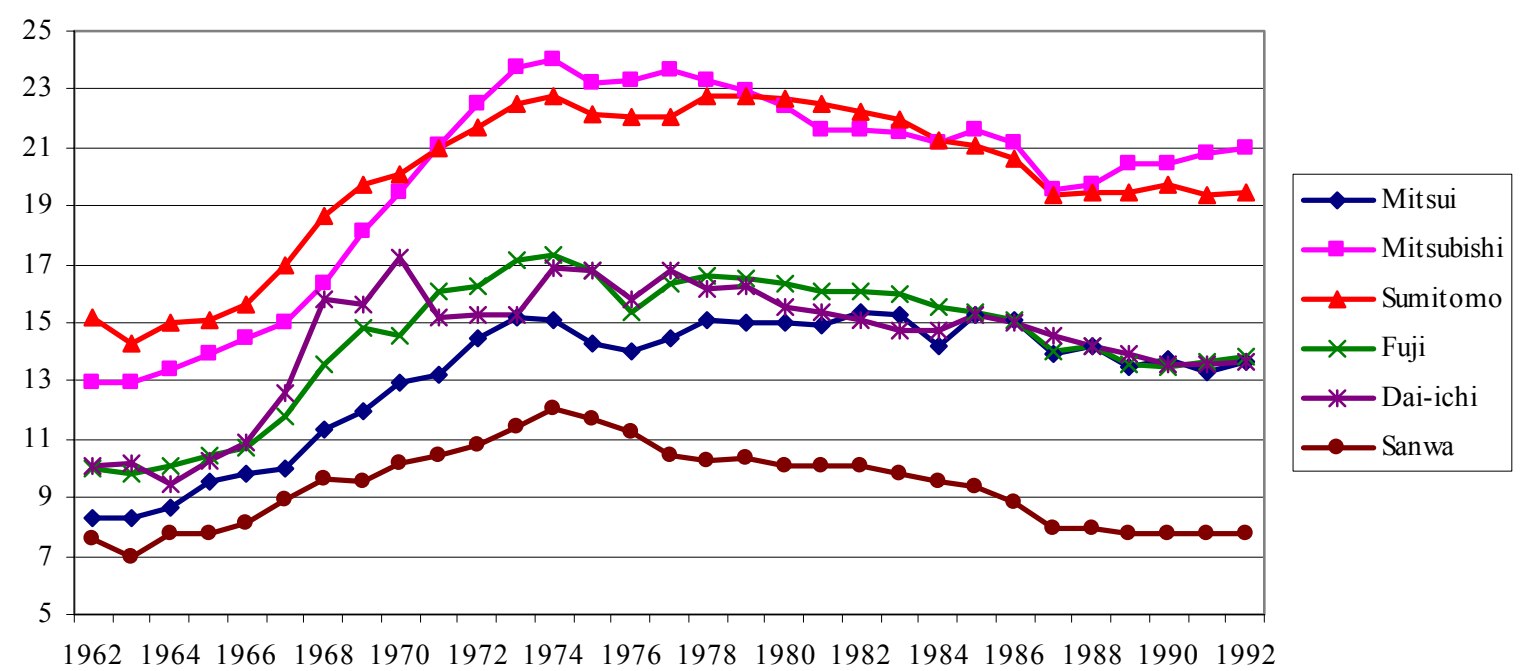

Source: Keizai Chosa Kai (various years), Keiretsu no Kenkyu. 
Table 1: Employment in foreign affiliates as a share of total employment (in \%)

\begin{tabular}{|c|c|c|c|c|c|}
\hline Code & Industry & $\begin{array}{c}\text { JAFF } \\
(33.4 \%) \\
1996\end{array}$ & $\begin{array}{c}\text { JAFF } \\
(33.4 \%) \\
2001\end{array}$ & $\begin{array}{c}\text { JAFF } \\
(20 \% \text {, } \\
\text { single } \\
\text { owner) } \\
2001\end{array}$ & $\begin{array}{c}\text { USAFF } \\
(10 \% \text {, } \\
\text { single } \\
\text { owner) } \\
1997\end{array}$ \\
\hline & Total all sectors & n.a. & 1.15 & 2.75 & 5.61 \\
\hline & Manufacturing total & 1.36 & 1.94 & 5.91 & 10.78 \\
\hline 03 & Food products & 0.29 & 0.34 & 1.32 & 8.38 \\
\hline 04 & Textiles \& apparel & 0.15 & 0.17 & 0.93 & 5.83 \\
\hline 05 & Wood and paper products & 0.06 & 0.16 & 0.83 & 4.95 \\
\hline 06 & Publishing \& printing & 0.13 & 0.22 & 0.38 & 7.83 \\
\hline 07 & Chemical products & 3.61 & 3.27 & 13.50 & 21.80 \\
\hline 08 & Drugs \& medicine & 7.21 & 15.49 & 15.27 & 31.90 \\
\hline 09 & Petroleum and coal products & 7.24 & 2.91 & 2.31 & 22.20 \\
\hline 10 & Plastic products & 0.41 & 0.45 & 3.22 & 10.03 \\
\hline 11 & Rubber products & 1.08 & 1.15 & 2.81 & 40.18 \\
\hline 12 & Ceramic, stone and clay & 0.28 & 0.35 & 1.55 & 21.45 \\
\hline 13 & Iron \& steel & 0.01 & 0.13 & 0.27 & 19.35 \\
\hline 14 & Non-ferrous metals & 1.61 & 0.44 & 7.72 & 15.73 \\
\hline 15 & Metal products & 0.31 & 0.20 & 0.72 & 7.52 \\
\hline 16 & General machinery & 1.68 & 1.78 & 6.82 & 12.75 \\
\hline 17 & Electrical machinery & 2.46 & 2.48 & 12.51 & 13.78 \\
\hline 18 & Motor vehicles \& parts & 4.72 & 10.79 & 18.32 & 15.60 \\
\hline 19 & Miscellaneous transport equipment & 0.7 & 0.62 & 12.71 & 4.23 \\
\hline 20 & Precision instruments & 0.41 & 0.90 & 5.04 & 11.16 \\
\hline \multirow[t]{2}{*}{21} & Miscellaneous manufacturing & 0.47 & 0.72 & 1.71 & 6.62 \\
\hline & Services total & 0.65 & 0.97 & 2.04 & 4.31 \\
\hline 22 & Construction \& civil engineering & 0.05 & 0.05 & 0.30 & 1.72 \\
\hline 23 & Electricity, gas, steam and water supply, etc. & 0.00 & 0.00 & 0.04 & 1.96 \\
\hline 24 & Wholesale trade & 2.31 & 2.57 & 4.24 & 7.89 \\
\hline 25 & Retail trade & 0.29 & 0.49 & 0.77 & 4.50 \\
\hline 26 & Financial intermediary services & 1.47 & 1.75 & 10.00 & 6.10 \\
\hline 27 & Insurance & 1.67 & 6.69 & 12.57 & 6.40 \\
\hline 28 & Real estate & 0.02 & 0.08 & 0.28 & 1.64 \\
\hline 29 & Transportation \& postal service & 0.50 & 0.27 & 3.52 & 4.82 \\
\hline 30 & Telecommunications \& broadcasting & 0.22 & 2.31 & 6.55 & 7.66 \\
\hline 31 & Education \& research institutes & 0.34 & 0.97 & 1.76 & 6.39 \\
\hline 32 & Medical services, health and hygiene & 0.02 & 0.04 & 0.16 & 1.99 \\
\hline 33 & Computer programming \& information services & 1.83 & 2.55 & 4.33 & 3.88 \\
\hline 34 & Goods \& equipment rental $\&$ leasing & 0.88 & 1.20 & 0.49 & 3.66 \\
\hline 35 & Other business services & 0.52 & 1.71 & 2.10 & 4.77 \\
\hline 36 & Eating \& drinking places & 1.58 & 2.36 & 3.89 & 2.48 \\
\hline 37 & Other personal services & 0.12 & 0.39 & 0.38 & 4.23 \\
\hline 38 & Other services & 0.01 & 0.00 & 0.00 & n.a. \\
\hline
\end{tabular}

Sources: Compiled from micro-data of METI's Establishment and Enterprise Census for 1996 and 2001 and Bureau of Economic Analysis, Foreign Direct Investment in the United States: Establishment Data for 1997, online: <http://www.bea.gov/bea/ai/iidguide.htm\#FDIUS> (accessed 18 Feb. 2005).

Notes: JAFF (33.4\%): Japanese Affiliates of Foreign Firms (33.4\% or more foreign-owned, one or more foreign companies); JAFF (20\%): Japanese Affiliates of Foreign Firms (20\% or more foreign-owned by a single foreign company); USAFF: U.S. Affiliates of Foreign Firms (10\% or more foreign-owned by a single foreign company). 
Table 2: Share of foreign direct investment in Japan by industry, 1989-2003 (in \%)

\begin{tabular}{lrrr}
\hline & $1989-1997$ & $1998-2003$ & $1989-2003$ \\
\hline Food & 1.0 & 0.9 & 0.9 \\
Textile & 0.2 & 0.1 & 0.1 \\
Rubber and leather & 1.4 & 0.1 & 0.5 \\
Chemical & 14.1 & 6.9 & 8.7 \\
Metal & 3.0 & 0.3 & 1.0 \\
Machinery & 19.9 & 15.9 & 16.9 \\
Petroleum & 1.6 & 2.7 & 2.4 \\
Glass and ceramics & 0.1 & 0.1 & 0.1 \\
Other manufacturing & 2.1 & 0.8 & 1.1 \\
\hline Manufacturing total & 43.3 & 27.9 & 31.8 \\
\hline Telecommunication & 0.9 & 16.2 & 12.3 \\
Construction & 0.1 & 0.1 & 0.1 \\
Trading & 21.9 & 11.5 & 14.1 \\
Finance and insurance & 12.0 & 32.4 & 27.2 \\
Service & 14.9 & 9.6 & 10.9 \\
Transportation & 0.5 & 0.2 & 0.2 \\
Real Estate & 5.0 & 2.0 & 2.7 \\
Other & 1.4 & 0.2 & 0.5 \\
\hline Non-manufacturing total & 56.7 & 72.1 & 68.2 \\
\hline TOTAL & 100.0 & 100.0 & 100.0 \\
\hline Source: Authors' calculation & 10.0 &
\end{tabular}

Source: Authors' calculations based on Ministry of Finance, online:

$<$ http://www.mof.go.jp/english/e1c008.htm> (accessed 18 Feb. 2005). 
Table 3: The process of FDI liberalization in Japan

\begin{tabular}{|c|c|c|c|c|c|}
\hline & \multirow{2}{*}{\multicolumn{3}{|c|}{$\frac{\text { For newly established firms }}{\text { Number of industries }}$}} & \multirow{2}{*}{\multicolumn{2}{|c|}{$\frac{\text { For existing firms in all industries }}{\text { Foreign ownership }}$}} \\
\hline & & & & & \\
\hline & $\begin{array}{l}\text { Up to } 50 \% \\
\text { foreign owner- } \\
\text { ship permitted }\end{array}$ & $\begin{array}{l}\text { Up to } 100 \% \\
\text { foreign owner- } \\
\text { ship permitted }\end{array}$ & Total & $\begin{array}{l}\text { By one foreign } \\
\text { "person" } \\
(* 1)\end{array}$ & $\begin{array}{l}\text { By all foreign } \\
\text { "persons" }(* 1)\end{array}$ \\
\hline \multicolumn{6}{|l|}{$\begin{array}{l}\text { Japan joins OECD, } \\
\text { accepts IMF's Article } 8 \\
(1964)\end{array}$} \\
\hline $\begin{array}{l}\text { Phase I } \\
\text { (July 1967) }\end{array}$ & 33 & 17 & 50 & Up to $7 \%$ & Up to $20 \%$ \\
\hline $\begin{array}{l}\text { Phase II } \\
\text { (March 1969) }\end{array}$ & 160 & 44 & 204 & Up to $7 \%$ & Up to $20 \%$ \\
\hline $\begin{array}{l}\text { Phase III } \\
\text { (Sept. 1970) }\end{array}$ & 447 & 77 & 524 & Up to $7 \%$ & Less than $25 \%$ \\
\hline $\begin{array}{l}\text { Automobile industry } \\
\text { liberalization (June 1971) }\end{array}$ & \multicolumn{3}{|c|}{$\begin{array}{l}\text { Automobile and } 5 \text { related industries (automatic approval } \\
\text { for up to } 50 \% \text { foreign ownership) }\end{array}$} & & \\
\hline $\begin{array}{l}\text { Phase IV } \\
\text { (Aug. 1971) }\end{array}$ & $\begin{array}{l}\text { All industries } \\
\text { other than those } \\
100 \% \text { liberal- } \\
\text { ized (next col- } \\
\text { umn) and } 7 \text { in- } \\
\text { dustries subject } \\
\text { to individual } \\
\text { screening }(* 2)\end{array}$ & 228 & - & Less than $10 \%$ & Less than $25 \%$ \\
\hline $\begin{array}{l}\text { Phase V } \\
\text { (May 1973) }\end{array}$ & \multicolumn{3}{|c|}{$\begin{array}{l}\text { In principle, "complete liberalization", with the } \\
\text { exception of } 22 \text { industries }(17 \text { of which subject to } \\
\text { delayed liberalization) }(* 3)\end{array}$} & \multicolumn{2}{|c|}{$\begin{array}{l}100 \% \text { foreign ownership allowed } \\
\text { (excluding } 22 \text { specified industries), } \\
\text { but only with consent of target } \\
\text { firm }\end{array}$} \\
\hline $\begin{array}{l}\text { Liberalization of the } 17 \\
\text { industries subject to } \\
\text { delayed liberalization } \\
\text { (Dec. } 1974 \text { to May } 1976 \text { ) }\end{array}$ & \multicolumn{5}{|c|}{$\begin{array}{l}\text { Dec. 1974: Integrated circuits. } \\
\text { May 1975: Meat products, tomato processed products, prepared feed for animals, pharmaceu- } \\
\text { ticals and agricultural chemicals, ferroalloy, music records, real estate, electronic precision } \\
\text { machinery, packing machinery, oil pressure instruments, apparel (including wholesale trade } \\
\text { of apparel), prepared food products for food service industry. } \\
\text { Dec. 1975: Manufacture of computers, sale and leasing of computers. } \\
\text { April 1976: Information services. }\end{array}$} \\
\hline \multicolumn{6}{|l|}{$\begin{array}{l}\text { Retail trade liberalization } \\
\text { (June 1975) }\end{array}$} \\
\hline $\begin{array}{l}\text { Amendment to the } \\
\text { Foreign Exchange Law } \\
\text { (Dec. 1980) }\end{array}$ & \multicolumn{5}{|c|}{$\begin{array}{l}\text { Change from prior permission of FDI to prior notification to the Ministry of Finance and other } \\
\text { Ministries in charge of the industry concerned to determine whether an inquiry was necessary. } \\
\text { Takeover by foreigner(s) no longer requires consent of acquired firm. }\end{array}$} \\
\hline $\begin{array}{l}\text { Abolition of the "System } \\
\text { of Restricting Foreign } \\
\text { Participation in } \\
\text { Designated Companies" } \\
\text { (Shitei Kaisha Seido) } \\
\text { (July 1984) }\end{array}$ & \multicolumn{5}{|c|}{$\begin{array}{l}\text { Under this system, foreign investments in the following } 11 \text { companies were subject to } \\
\text { government assessment for national security reasons: Hitachi, Fuji Electric, Katakura } \\
\text { Industries, Tokyo Keiki, Tokimec, Arabian Oil, General Sekiyu (now: TonenGeneral Sekiyu), } \\
\text { Showa Sekiyu (now: Showa Shell Sekiyu), Mitsubishi Sekiyu (now: Mitsubishi Shoji Sekiyu, } \\
\text { Koa Oil (now: Nippon Oil). }\end{array}$} \\
\hline $\begin{array}{l}\text { Amendments to the } \\
\text { Foreign Exchange Law } \\
\text { (Jan. 1992) }\end{array}$ & \multicolumn{5}{|c|}{$\begin{array}{l}\text { Change to ex post facto reporting of FDI; only in certain cases, prior notification to the } \\
\text { Ministry of Finance and other Ministries in charge of the industry concerned required to } \\
\text { determine whether an inquiry is necessary. }\end{array}$} \\
\hline $\begin{array}{l}\text { Amendments to the } \\
\text { Foreign Exchange Law } \\
\text { (April 1998) }\end{array}$ & \multicolumn{5}{|c|}{$\begin{array}{l}\text { FDI in telecommunications and broadcasting was changed from prior notification to ex post } \\
\text { facto reporting. }\end{array}$} \\
\hline
\end{tabular}

Notes:

(*1) The term "person" refers to any natural person, any government or its representatives, or any juridical person or association.

$(* 2)$ The seven industries subject to screening were: 1. Agriculture, fishery, and forestry; 2 . Petroleum refinery and sales of refined petroleum; 3. Production of leather products; 4. Production, sales and leasing of computers; 5. Information processing; 6 . Retail activity with more than eleven shops; 7 . Real estate.

(*3) The remaining five of the 22 exceptions were: 1 . Agriculture, fishery, and forestry; 2. Oil; 3. Mining; 4.

Leather and leather product manufacturing; 5. Retail trade.

Source: Compiled by authors based on Nakamura, Fukao, and Shibuya (1997), Sangyo Kenkyusho (1983), MITI, Tsusho Sangyo Seisakushi Hensan Iinkai Hen (1991), APEC (1999). 
Table 4: Exceptions to national treatment

Foreign direct investment in Japan is subject to the Foreign Exchange and Foreign Trade Law. In addition to general stipulations, the Law contains the following exceptions to national treatment for the purpose of foreign investment.

\begin{tabular}{|l|l|}
\hline Sector & Restriction \\
\hline Air transport & $\begin{array}{l}\text { A license to operate a domestic air transport business shall only be granted to } \\
\text { a juridical person or association with less than a third of voting rights } \\
\text { controlled by foreigners. }\end{array}$ \\
\hline Maritime transport & $\begin{array}{l}\text { Transport of goods and passengers between Japanese ports is reserved to } \\
\text { Japanese ships. Foreign ownership of Japanese ships can be obtained only } \\
\text { through an enterprise incorporated in Japan in accordance with Ship Law. }\end{array}$ \\
\hline Telecommunications & $\begin{array}{l}\text { Foreign capital participation in Nippon Telegraph and Telephone Corporation } \\
\text { (NTT) is restricted to less than one-third. }\end{array}$ \\
\hline Broadcasting & $\begin{array}{l}\text { Foreigners or foreign-controlled enterprises (where any of the executive } \\
\text { officers is a foreigner, or one-fifth or more of voting rights in aggregate are } \\
\text { owned by foreigners) are not granted licenses for broadcasting stations or } \\
\text { approvals for program-supplying broadcast business. }\end{array}$ \\
$\begin{array}{l}\text { Foreigners or foreign-controlled enterprises (where any of the corporate } \\
\text { representatives is a foreigner, or one third or more of voting rights in aggregate } \\
\text { are owned by foreigners) are not granted licenses for broadcasting stations of } \\
\text { facility-supplying broadcasting or licenses for broadcasting stations used for } \\
\text { relay broadcasting for preventing reception disturbance. }\end{array}$ \\
\hline Mining & $\begin{array}{l}\text { No one other than Japanese citizens or Japanese juridical persons shall } \\
\text { become mining right owners. }\end{array}$ \\
\hline Banking & $\begin{array}{l}\text { The deposit insurance system only covers financial institutions which have } \\
\text { their head office in Japan. Branches of foreign banks in Japan are not covered } \\
\text { by the Deposit Insurance Law, mainly because jurisdictional problems might } \\
\text { hinder Japanese authorities in taking prompt and appropriate action against } \\
\text { them at the time of resolution of failed financial institutions. }\end{array}$ \\
\hline
\end{tabular}

Source: Adapted from APEC, Guide to the Investment Regimes of the APEC Member Economies, Fifth Edition, 2003; online: <http://www.apec.org/apec/publications/free_downloads/2003.html> (accessed 18 Feb. 2005). 